\title{
When Is External Debt Sustainable?
}

\author{
Aart Kraay and Vikram Nehru
}

\begin{abstract}
The article empirically examines the determinants of debt distress, defined as periods in which countries resort to any of three forms of exceptional finance: significant arrears on external debt, Paris Club rescheduling, and nonconcessional International Monetary Fund lending. Probit regressions show that three factors explain a substantial fraction of the crosscountry and time-series variation in the incidence of debt distress: the debt burden, the quality of policies and institutions, and shocks. The relative importance of these factors varies with the level of development. These results are robust to a variety of alternative specifications, and the core specifications have substantial out-of-sample predictive power. The quantitative implications of these results are examined for the lending strategies of official creditors.
\end{abstract}

This article empirically analyzes the probability of debt distress in developing countries and examines the implications of the results for the lending policies of official creditors. It defines debt distress episodes as periods in which countries resort to any of three forms of exceptional finance: substantial arrears on their external debt, debt relief from the Paris Club of creditors, and nonconcessional balance of payments support from the International Monetary Fund (IMF). Three factors-the debt burden, the quality of institutions and policies, and shocks that affect real GDP growth-are found to be highly significant predictors of debt distress, and their relative importance differs between low- and middle-income countries.

Three features of this article distinguish it from much of the large empirical literature on debt sustainability. First, one of the main interests is in understanding the determinants of debt distress among low-income countries, which have been at the center of recent debt relief efforts such as the 1996 Heavily Indebted Poor Countries (HIPC) Initiative and the 2006 Multilateral Debt Relief Initiative. In contrast, much of the existing empirical literature focuses on debt crises in middle-income countries that borrow primarily from private creditors. As shown below, the features of distress episodes and their determinants are quite different in the two groups of countries.

Aart Kraay is lead economist in the Development Research Group at the World Bank; his email address is akraay@worldbank.org. Vikram Nehru is director of the Economic Policy and Debt Department at the World Bank; his email address is vnehru@worldbank.org. The authors thank Nancy Birdsall, Christina Daseking, Gershon Feder, Alan Gelb, Indermit Gill, Rex Ghosh, Nicholas Hope, and Sona Varma for helpful comments; Carmen Reinhart for kindly sharing historical data on default episodes; and Sunyoung Lee for superb research assistance.

THE WORLD BANK ECONOMIC REVIEW, VOL. 20, NO. 3, pp. 341-365

doi:10.1093/wber/lhl006

Advance Access publication August 28, 2006

(C) The Author 2006. Published by Oxford University Press on behalf of the International

Bank for Reconstruction and Development / THE WORLD BANK. All rights reserved. For permissions, please e-mail: journals.permissions@oxfordjournals.org. 
Second, this analysis finds that nonfinancial variables, especially the quality of policies and institutions, are key determinants of debt distress in low-income countries. The idea that policies and institutions matter for debt sustainability is not novel. But it has received relatively little attention in the empirical literature. A notable exception is Reinhart, Rogoff, and Savastano (2003), who document the importance of a country's history of nonrepayment and macroeconomic instability in driving market perceptions of the likelihood of default. The analysis here complements theirs by showing that not only does the history of nonrepayment and weak policy matter for the likelihood of debt distress but so do contemporaneous policies and institutions. Moreover, this article finds that the contemporaneous effect of improvements in policies and institutions on the probability of debt distress is quantitatively large and roughly of the same order of magnitude as reductions in debt burdens. It also finds that the role of policies and institutions is much more important in low-income countries than in middle-income countries.

Third, the article emphasizes the implications of the findings for the lending strategies of multilateral concessional creditors such as the World Bank and the IMF. In these organizations notions of debt sustainability have until recently focused almost exclusively on simple projections of debt burden indicators and their comparison with fairly arbitrary benchmarks. For example, debt relief under the HIPC Initiative was calibrated to ensure that countries emerge from the process with a present value of debt to exports of 150 percent, irrespective of other country characteristics. The results here indicate that a common single debt sustainability threshold is not appropriate because it fails to recognize the role of institutions and policies that matter for the likelihood of debt distress. In particular, the results permit summarizing striking tradeoffs between debt indicators, policies, and shocks for a given probability of debt distress. For example, the benchmark results suggest that countries at the 75 th percentile of the measure of policies and institutions can have a present value of debt to exports that is two to three times higher than countries at the 25 th percentile of this indicator, without increasing the probability of debt distress. These tradeoffs suggest that a country's targeted level of "sustainable" debt should vary substantially with the quality of its policies and institutions.

This work is premised on the view that avoiding debt distress is desirable. There are several reasons for this. Resolving debt distress imposes direct costs in terms of the time that debtors and creditors must spend coordinating and renegotiating claims. Excessive debt can also undercut support for policy reforms by political and civil society groups in debtor countries if they perceive that benefits from reforms will be directed to high debt service rather than to needed public services for the poor. The pressure to meet external debt service payments may also tempt debtor country governments to seek short-term solutions at the expense of fundamental, longer-term reforms. Creditors, as well, may be tempted to allocate resources according to resource needs rather than policy performance. ${ }^{1}$ Finally,

1. For example, Birdsall, Claessens, and Diwan (2003) argue that the correlation between aid and policy performance is weak in highly indebted countries in sub-Saharan Africa. 
nonrepayment of loans to multilateral lenders can have perverse distributional effects among borrowing countries. Absent new resources from donors, the failure to repay concessional loans reduces the ability of multilateral creditors to provide new loans to other developing countries. Moreover, to the extent that new lending is intended for countries with sound policies and institutions, whereas countries with poor policies and institutions are more likely to fail to service their past debts, the result can be a transfer of resources from countries with good policies to countries with bad policies. ${ }^{2}$

This article is obviously not the first to empirically investigate the determinants of debt servicing difficulties. The debt crisis of the early 1980s prompted a surge of empirical work. An early contribution is by McFadden and others (1985), who construct an indicator of debt servicing difficulties based on arrears, rescheduling, and IMF support, much like the one used here, for 93 countries over the period 1971-1982. They find that the debt burden, the level of per capita income, real GDP growth, and liquidity measures such as nongold reserves are significant predictors of debt distress, whereas real exchange rate changes are not. They also investigate the importance of state dependence and country effects and conclude that both matter, whereas the updated sample used here does not find comparable evidence of state dependence. Other studies in the early literature include that of Cline (1984), who focuses primarily on financial variables such as the determinants of debt servicing difficulties, and of Berg and Sachs (1988), who emphasize "deep" structural factors such as income inequality (which they argue proxies for political pressures for excessive borrowing) and a lack of trade openness as determinants of debt servicing difficulties among middle-income countries. In addition, Lloyd-Ellis, McKenzie, and Thomas (1990) model both the probability of debt reschedulings and their magnitude, again emphasizing financial variables. Interestingly, none of these studies focuses on direct measures of the quality of policies and institutions, as this one does. ${ }^{3}$

2. The amounts at stake are nontrivial. Consider the World Bank-administered International Development Association (IDA), which provides substantial resources to the world's poorest countries. As of 2003, IDA's portfolio consisted of highly concessional loans with a face value of roughly $\$ 110$ billion. During fiscal 2003 it disbursed $\$ 7$ billion in new loans, of which only $\$ 1.4$ billion was financed by repayments on existing loans and with most of the balance coming from infusions from rich countries. Given the long grace periods in IDA lending, this flow of repayments is anticipated to increase sharply in the future, averaging $\$ 2.3$ billion a year over 2003-2008, $\$ 3.3$ billion a year over the next five years, and $\$ 4.2$ billion in the five years after that (World Bank 2003). Holding constant future donor contributions to IDA, it is clear that any disruption in this flow of future repayment resulting from episodes of debt distress will have significant implications for IDA's ability to provide new lending to the poorest countries.

3. Another strand of this early literature tried to find a discontinuity in the relationship between debt burden indicators (usually the external debt to export ratio) and the incidence of default or market-based indicators of risk (such as the premium over benchmark interest rates on debt securities traded in the secondary market), for example, Underwood (1991) and Cohen (1996). These studies found that above a threshold range of about 200-250 percent of the present value of the debt to export ratio, the likelihood of debt default climbed rapidly. This range then became the benchmark adopted by the original HIPC Initiative in 1996 but was subsequently lowered in 1999 under the Enhanced HIPC framework. 
Several more recent studies are also related to this work. Aylward and Thorne (1998) empirically investigate countries' repayment performance to the IMF, emphasizing the importance of countries' repayment histories and IMF-specific financial variables in predicting the likelihood of arrears. McKenzie (2004) studies the determinants of default on World Bank loans. Detragiache and Spilimbergo (2001) study the importance of liquidity factors such as shortterm debt, debt service, and the level of international reserves in predicting debt crises.

Reinhart, Rogoff, and Savastano (2003) study the historical determinants of "debt intolerance," a term used to describe the extreme duress that many emerging market economies experience at debt levels that seem quite manageable by industrial country standards. Their most relevant finding to this work is that the Institutional Investor magazine's sovereign risk ratings can be explained by a very small number of variables measuring a country's repayment history, its external debt burden, and its history of macroeconomic stability. However, there are three key differences between their study and this article. First, their dependent variable, the Institutional Investor rating, measures perceptions of the probability of debt distress, whereas this article attempts to explain the incidence of actual episodes of debt distress. ${ }^{4}$ Second, their sample consists mostly of middle- and high-income countries, in contrast with the focus here on lowincome countries. Third, as shown in more detail below, this article finds that contemporaneous policy matters for the incidence of debt distress, whereas a history of bad policy and nonrepayment, a key determinant in their study, matters less.

Finally, the analysis by Manasse, Roubini, and Schimmelpfennig (2003) is most closely related to that in this article. They consider a country to be in debt crisis if it is classified as being in default by Standard \& Poor's or if it has access to nonconcessional IMF financing in excess of 100 percent of quota. They use logit and binary recursive tree analysis to identify macroeconomic variables reflecting solvency and liquidity factors that predict a debt crisis episode one year in advance. Once again, the key difference with the analysis in this article is that they restrict their analysis to a sample of emerging market developing countries for which such data are available (especially the Standard \& Poor's data), whereas a special focus of this article is the factors affecting debt distress in low-income countries. Several of their key results, however, are broadly consistent with those found here. They find that debt burden indicators and GDP growth, as well as a somewhat different set of measures of policies and institutions, significantly influence the likelihood of debt crises.

The following section describes in detail the methodology for identifying debt distress episodes. Section II documents the relative importance of debt burdens, a measure of policies and institutions, and shocks in driving debt distress. It shows

4. As documented in Reinhart, Rogoff, and Savastano (2003), country risk ratings are only imperfect predictors of actual default episodes. 
that these three variables have substantial out-of-sample forecasting power for debt distress events and that the results survive several robustness checks. Section III presents some policy implications of the results.

\section{EMPIRICAL FrameWORK}

The sample consists of all 132 low- and middle-income countries that report debt data in the World Bank's Global Development Finance publication and covers all years during 1970-2002 for which the necessary data are available. The Appendix describes the data sources.

\section{Identifying Debt Distress Episodes}

Episodes of debt distress are defined as periods in which any one or more of the following three conditions hold: the sum of interest and principal arrears is large relative to the stock of debt outstanding, a country receives debt relief in the form of rescheduling or debt reduction from the Paris Club of bilateral creditors, or the country receives substantial balance of payments support from the IMF under its nonconcessional Standby Arrangements or Extended Fund Facilities. The first condition is the basic measure of debt distress: the failure to service external obligations resulting in an accumulation of arrears. But countries that are unable to service their external debt need not fall into arrears; they can also seek debt relief from the Paris Club or balance of payments support from the IMF. ${ }^{5}$ This is why the arrears criterion for debt distress is complemented by the other two criteria. As a control group, nondistress episodes, or "normal times," are defined as nonoverlapping periods of five consecutive years in which none of the three indicators of debt distress is observed. ${ }^{6}$

To implement the rule for identifying debt distress episodes, thresholds for "large" values of arrears and "substantial" levels of IMF support have to be identified. The threshold for arrears is 5 percent of total debt outstanding. For IMF programs only those for which commitments are greater than 50 percent of the country's IMF quota are considered. Although any threshold for defining debt distress episodes is somewhat arbitrary, these values are quite high relative to the experience of the typical developing country. The threshold for arrears, for example, is roughly 10 times greater than the median value of arrears as a fraction of debt outstanding (0.4 percent) when all country-years since 1970 are pooled. Similarly, the median value of IMF commitments relative to quota is zero for pooled country-year observations, reflecting the fact that less than half the country-years in the sample correspond to an IMF program including access to nonconcessional IMF facilities. When such programs are in place, the median

5. This article does not define debt reductions under the HIPC Initiative as a separate indicator of debt distress because all debt relief under the Initiative requires parallel debt reduction by the Paris Club.

6. These episodes begin in the first year for which it is possible to find five consecutive years with no distress. 
Figure 1. Identifying Debt-Distress Events: Example of Kenya

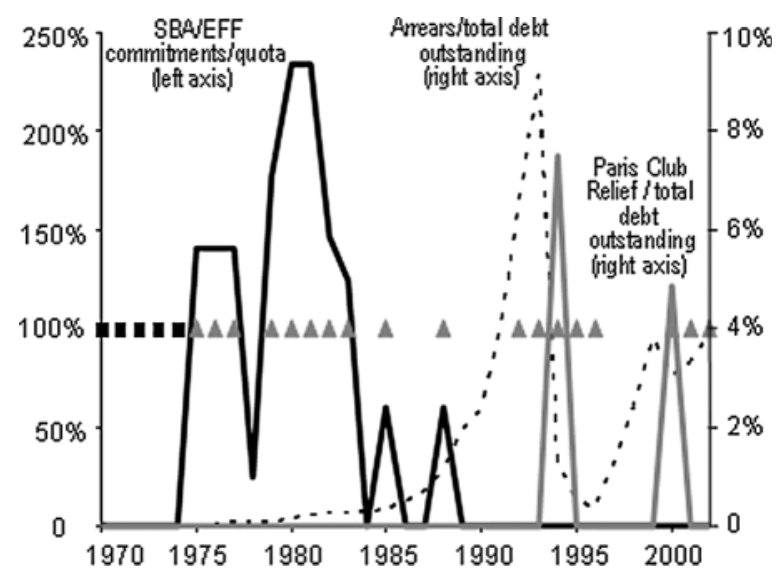

Source: Authors' analysis of data described in Appendix.

commitment is 52 percent of quota. This means that the threshold identifies only the top half (in terms of committments relative to quota) of all Standby Arrangement and Extended Fund Facility programs. ${ }^{7}$ Finally, for Paris Club agreements the year of the agreement and the two subsequent years are identified as distress episodes because most Paris Club agreements provide relief for debt service payments falling due during a fairly short period, typically three years.

Figure 1 illustrates how normal and debt distress episodes are identified for the case of Kenya. It shows commitments under Standby Arrangements or Extended Fund Facilities (sBA/EFF) (solid black line), arrears (dashed line), and Paris Club relief (gray line). During the 1970s and 1980s Kenya received balance of payments support in excess of 50 percent of its quota for a total of 10 years, whereas during the 1990s it had four years in which arrears were more than 5 percent of debt outstanding. Finally, it also received substantial Paris Club relief in 1994 and again in 2000. This means that in total, between 1970 and 2000, Kenya experienced 17 years of debt distress (indicated by triangles). In contrast, it managed only one five-year period of normal times, beginning in 1970, in which there were no arrears, debt relief, or IMF support (indicated by squares).

In Kenya and in many other countries, episodes of debt distress are often quite short and are also often immediately preceded by other distress episodes. To be sure that episodes of prolonged debt distress rather than sporadic fluctuations in the distress indicator are being identified, all short distress episodes of less than

7. Access to the Poverty Reduction and Growth Facility of the IMF is not included as a debt distress indicator, because in many cases financing from this facility is no longer to meet temporary payments imbalances but has become a source of long-term development finance. See IMF (2002). 
Table 1. Distress Episodes

\begin{tabular}{|c|c|c|c|c|c|}
\hline Albania & 1992-2002 & Ecuador & 1983-1996 & Malawi & 1979-1985 \\
\hline Algeria & 1994-1997 & Ecuador & 2000-2002 & Niger & 1983-1990 \\
\hline Argentina & 1983-1995 & $\begin{array}{l}\text { Egypt, Arab } \\
\text { Rep. }\end{array}$ & 1984-1995 & Nigeria & 1986-2002 \\
\hline Bangladesh & 1979-1981 & Ethiopia & 1991-2002 & Nicaragua & 1983-2002 \\
\hline Benin & 1983-1998 & Ghana & 1996-1998 & Pakistan & 1980-1983 \\
\hline Brazil & 1983-1985 & Guinea-Bissau & 1981-2002 & Pakistan & 1995-2002 \\
\hline Brazil & 1998-2002 & Guyana & 1978-2002 & Paraguay & 1986-1994 \\
\hline Bulgaria & 1991-2000 & Honduras & 1979-2001 & Rwanda & 1994-2002 \\
\hline Burkina Faso & 1987-1998 & Haiti & 1978-1980 & Senegal & 1980-2002 \\
\hline Burundi & 1998-2002 & Indonesia & 1997-2002 & El Salvador & 1990-1992 \\
\hline Cameroon & 1987-2002 & India & $1981-1983$ & Somalia & 1981-2002 \\
\hline Chile & 1983-1989 & Jordan & 1989-2002 & Seychelles & 1990-2002 \\
\hline Côte d'Ivoire & 1981-1996 & Kenya & 1992-1996 & Thailand & 1997-1999 \\
\hline Congo, Rep. & $1985-2002$ & Kenya & $2000-2002$ & $\begin{array}{c}\text { Trinidad and } \\
\text { Tobago }\end{array}$ & 1988-1992 \\
\hline Colombia & 1999-2001 & Cambodia & 1989-2002 & Tunisia & 1986-1991 \\
\hline Comoros & 1987-2002 & Liberia & 1980-2002 & Turkey & 1978-1984 \\
\hline Cape Verde & $1988-2002$ & Morocco & 1980-1994 & Turkey & 1999-2002 \\
\hline Costa Rica & 1980-1995 & Madagascar & 1980-2002 & Uruguay & 1983-1986 \\
\hline Dominican & 1983-1999 & Mexico & 1983-1992 & Vietnam & 1988-2002 \\
\hline Republic & & & & Zimbabwe & 2000-2002 \\
\hline
\end{tabular}

Source: Authors' analysis of data described in Appendix.

three-year duration are eliminated. So are all distress episodes preceded by periods of distress in any of the three previous years to ensure that distinct episodes of distress are being identified, as opposed to continuations of previous episodes. This procedure identifies a total of 100 episodes of debt distress and 309 episodes of normal times over 1970-2002. ${ }^{8}$ For Kenya this results in two distress episodes, 1992-1996 and 2000-2002. The regression analysis that follows works with a subset of 58 distress episodes and 142 normal time episodes over 1978-2002 for which data on the core explanatory variables are available. The key constraint here is the preferred measure of policy used in the analysis, the World Bank's Country Policy and Institutional Assessment (CPIA) ratings, which began in 1978.

These 58 distress episodes are listed in table 1, and the means of key variables in distress and normal time periods are listed in table 2. The list contains many familiar episodes, including those in many Latin-American countries during the

8. The criteria for defining episodes imply that not all country-year observations will belong to either a distress episode or a nondistress episode. Of the 3,553 country-year observations for which indicators of distress are available, at least one indicator of distress is observed in 1,540 of them, with the remainder corresponding to nondistress years. After short distress episodes, distress episodes preceded by other episodes, and nondistress episodes shorter than five years are discarded, 2,630 country-years remain, of which 1,085 correspond to distress episodes. The regression sample is smaller still because of limits on the availability of explanatory variables and covers 1,339 country-years, of which 629 are classified as distress. 
Table 2. Means of Key Variables in Normal Times and Distress Events

\begin{tabular}{|c|c|c|c|c|c|c|}
\hline & \multicolumn{2}{|c|}{ All Observations } & \multicolumn{2}{|c|}{$\begin{array}{l}\text { Low-Income } \\
\text { Countries }\end{array}$} & \multicolumn{2}{|c|}{$\begin{array}{l}\text { Middle-Income } \\
\text { Countries }\end{array}$} \\
\hline & Normal & Distress & Normal & Distress & Normal & Distress \\
\hline Average length of episode (years) & 5.0 & 10.8 & 5.0 & 12.6 & 5.0 & 8.7 \\
\hline \multicolumn{7}{|l|}{ Average during episode of } \\
\hline Arrears/debt & 0.006 & 0.094 & 0.005 & 0.133 & 0.006 & 0.046 \\
\hline Paris Club relief/debt & 0.000 & 0.017 & 0.000 & 0.018 & 0.000 & 0.016 \\
\hline IMF lending $\mathrm{a} /$ quota & 0.031 & 0.988 & 0.036 & 0.523 & 0.027 & 1.559 \\
\hline Net transfers/GDP & 0.014 & 0.005 & 0.031 & 0.021 & 0.005 & -0.014 \\
\hline \multicolumn{7}{|l|}{ Value before episode of } \\
\hline Present value of debt/exports & 0.818 & 1.724 & 1.089 & 1.956 & 0.666 & 1.440 \\
\hline $\begin{array}{l}\text { Country Policy and } \\
\text { Institutional Assessment (CPIA) }\end{array}$ & 3.789 & 3.084 & 3.489 & 2.849 & 3.957 & 3.374 \\
\hline Growth & 0.047 & 0.012 & 0.043 & 0.028 & 0.050 & -0.007 \\
\hline
\end{tabular}

${ }^{a}$ International Monetary Fund Standby Arrangement or Extended Fund Facility.

Source: Authors' analysis of data described in Appendix.

debt crisis of the 1980s and Thailand and Indonesia during the more recent East Asian financial crisis. There are also many lengthy episodes of debt distress in sub-Saharan Africa. ${ }^{9}$ A striking feature of the debt distress episodes is their length. In the regression sample the mean length of a distress episode is 10.8 years. The longest distress episode is that in the Central African Republic, which has been continuously in debt distress during the whole sample period, primarily because of high arrears. There are also very sharp differences in the values of the debt distress indicators between distress episodes and normal times. In distress episodes average arrears are 9.4 percent of debt outstanding, whereas in normal times average arrears are 0.5 percent. During distress episodes Standby Arrangement or Extended Fund Facility support averages 98 percent of quota, whereas during normal times it is 3 percent. Although by construction Paris Club relief is zero in normal times, it averages 1.7 percent of debt outstanding during distress episodes.

There are also interesting differences between low- and middle-income countries. Distress episodes tend to be longer in low-income countries (12.6 years) than in middle-income countries (8.7 years) and associated with higher levels of arrears (13.3 and 4.6 percent of debt outstanding). Net transfers on debt fall during distress episodes, but proportionately much less in low-income countries, where they decline from 3.1 to 2.1 percent of GDP on average, than in middle-income

9. One anomalous observation is Vietnam, which is identified as being in continuous debt distress since the late 1980s. This reflects continuous high levels of arrears relative to nonbilateral, non-Paris Club creditors, much of it ruble-denominated. In the vast majority of episodes of debt distress based on arrears, the arrears are primarily to multilateral and bilateral Paris Club creditors. 
countries, where they decline from 0.5 to -1.4 percent of GDP. This highlights a key feature of distress episodes in low-income countries-despite experiencing severe debt servicing difficulties, these countries on average continue to benefit from positive, and only somewhat reduced, net transfers on debt.

\section{Modeling the Probability of Debt Distress}

The following probit specification is used to model the probability of debt distress: ${ }^{10}$

$$
P\left[y_{c t}=1\right]=\Phi\left(\boldsymbol{\beta}^{\prime} \mathbf{X}_{c t}\right)
$$

where $y_{c t}$ is an indicator value taking a value of one for debt distress episodes and zero for normal time episodes, each beginning in country $c$ at time $t ; \Phi(\cdot)$ denotes the normal distribution function; $\mathbf{X}_{c t}$ denotes a vector of determinants of debt distress; and $\boldsymbol{\beta}$ is a vector of parameters to be estimated. The sample consists of unbalanced and irregularly spaced observations of distress and normal times. The core specification considers a very parsimonious set of potential determinants of debt distress. As a first step to alleviating concerns about potential endogeneity biases, each variable is measured in the year prior to the beginning of the episode. ${ }^{11}$

The core specifications consider three explanatory variables. The first is the present value of debt (the present value of future debt service obligations), expressed as a share of current exports. ${ }^{12}$ This is a useful summary of the overall debt burden of a country and reflects cross-country differences in the concessionality of debt. The second is the World Bank's CPIA ratings, which is used as the preferred measure of the policy environment. Available annually since 1978, the CPIA ratings reflect the perceptions of World Bank country economists. The third variable is real GDP growth, included as a crude way of capturing the various shocks, both exogenous and endogenous, that countries experience. There are substantial differences in the means of these variables before distress episodes and normal time episodes (see table 2). The present value of debt as a

10. Because the interest here is primarily the incidence of distress episodes rather than their precise timing, this simple probit specification is adequate. Collins (2003) shows how the timing of currency crises can be modeled explicitly as the first-passage time of a latent variable to a threshold, of which the simple probit specification here is a special case. Manasse, Roubini, and Schimmelpfenning (2003) suggest that binary recursive tree analysis better captures the nonlinearities in the relationship between debt crises and their determinants, in a sample of middle-income countries. We have not yet investigated whether similar nonlinearities are important in our sample.

11. For example, one might expect debt burdens to increase and policy performance to deteriorate during distress episodes. This would create a spurious correlation between these variables measured during the episode and the value of the outcome variable.

12. In the working paper version of this article (Kraay and Nehru 2004), several other debt burden indicators are also considered, including total debt service as a share of exports, the face value of debt relative to exports, debt service relative to current government revenues, and debt service relative to nongold reserves. Results for these measures were qualitatively similar, with the flow debt service measures providing slightly greater predictive power for debt distress. 
share of exports is more than twice as high before distress episodes (1.7) than before normal time episodes (0.8), policy is substantially worse (CPIA score of 3.1 and 3.8), and growth is considerably lower (1.2 and 4.7 percent).

Figure 2 illustrates the strong bivariate relationships between the core explanatory variables and the distress indicator. In each panel the sample of observations is divided by deciles of the explanatory variable of interest. The mean value of the explanatory variable is then computed by deciles and plotted against the mean of the distress indicator variable by decile. Thus, for example, in the first panel the mean value of the present value of debt to exports in the top decile of this variable is 3.4 , and 65 percent of the observations in this decile correspond to distress. In contrast, in the bottom decile the mean value of debt relative to exports is 13 percent, and only 11 percent of the observations in this decile correspond to distress. A key feature of the data is the strong relationship between debt distress and policy performance. In the lowest decile of policy

Figure 2. Correlates of Debt Distress

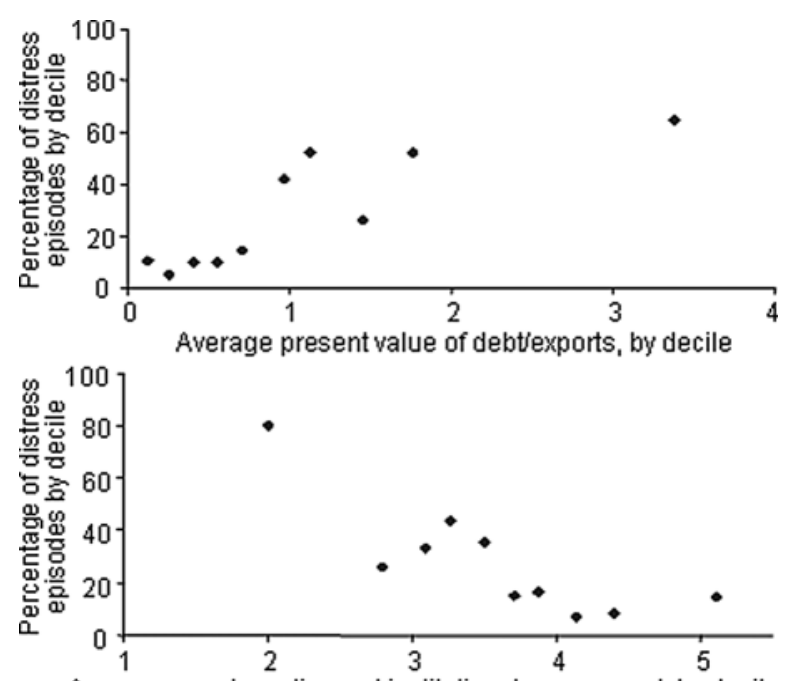

Average country policy and institutional assessment, by decile



Source: Authors' analysis of data described in Appendix. 
performance, fully 80 percent of observations correspond to distress, whereas in the top three deciles of policy performance the likelihood of debt distress is about 10 percent.

\section{Empirical Results}

This section confirms the importance of debt burdens, policies and institutions, and shocks in driving debt distress and shows the substantial out-of-sample forecasting power for debt distress events of these three variables. It also finds the results to be robust to several checks.

\section{Results from Core Specification}

Table 3 reports the core specifications. The observations for all countries show that debt burdens, policies, and shocks as proxied by real per capita GDP growth are all highly significant predictors of debt distress. Countries with high debt burdens, low CPIA scores, and low growth in a given year are significantly more likely to experience a debt distress episode beginning in the next year. The magnitude of the effects of debt and policy is economically significant as well. Moving from the 25th percentile of indebtedness to the 75th percentile raises the probability of distress from 15 to 35 percent (holding constant the other

Table 3. Basic Results

\begin{tabular}{|c|c|c|c|}
\hline & (1) & (2) & \multirow{2}{*}{$\begin{array}{c}\text { (3) } \\
\begin{array}{c}\text { Middle-Income } \\
\text { Countries }^{\mathrm{a}}\end{array}\end{array}$} \\
\hline & All & $\begin{array}{l}\text { Low-Income } \\
\text { Countries }^{\mathrm{a}}\end{array}$ & \\
\hline Present value debt/exports & $0.644(0.152) * * *$ & $0.143(0.074)^{*}$ & $0.262(0.060)^{* * * *}$ \\
\hline $\begin{array}{l}\text { Country Policy and } \\
\text { Institutional Assessment (CPIA) }\end{array}$ & $-0.557(0.142) * * *$ & $-0.311(0.091) * * *$ & $-0.020(0.051)$ \\
\hline Real GDP growth & $-4.620(2.085)^{* * *}$ & $-0.930(1.199)$ & $-2.080(0.749)^{* \ldots *}$ \\
\hline Constant & $0.821(0.512)$ & $1.911(0.789)^{* * *}$ & $-1.375(0.925)$ \\
\hline Number of observations & 200 & 83 & 117 \\
\hline $\begin{array}{l}\text { Out-of-sample predictive power } \\
\text { (fraction of events } \\
\text { correctly predicted) }\end{array}$ & & & \\
\hline All episodes & 0.71 & 0.75 & 0.78 \\
\hline Distress episodes & 0.74 & 0.56 & 0.70 \\
\hline Normal time episodes & 0.70 & 0.83 & 0.80 \\
\hline
\end{tabular}

"Significant at the 10 percent level.

$*$ :Significant at the 5 percent level.

***Significant at the 1 percent level.

Note: Numbers in parentheses are standard errors.

${ }^{\text {a }}$ Marginal effects rather than slope coefficients are reported for first three variables to facilitate a comparison of the magnitude of estimated effects between these two columns.

Source: Authors' analysis of data described in Appendix. 
variables at the median). Similarly, moving from the 25 th percentile of policy to the 75 th percentile lowers the probability of distress from 27 to 12 percent. The effect of growth, although significant, is not as large. Raising growth from the first to the third quartile lowers the probability of distress from 24 to 17 percent.

When the core specification is reestimated separately for low- and middleincome countries, higher debt burdens lead to significantly higher likelihood of debt distress in both groups of countries (see table 3 ). The magnitude of this effect is different in the two groups, however. To facilitate comparisons between these two groups, estimated marginal effects (the derivative of the probability of distress with respect to the variable of interest) are reported rather than the slope coefficients, $\boldsymbol{\beta}$. This marginal effect is nearly twice as large for middle-income countries as for low-income countries. In contrast, the marginal effect of policy is much larger among low-income countries than among middle-income countries, and in the second group it is not significantly different from zero. The effect of shocks, as proxied by real GDP growth, is much larger for middle-income countries than for low-income countries and is insignificant for low-income countries. The intercepts from the probit regressions is much larger for lowincome countries than for middle-income countries, suggesting that there are factors other than debt, policy, and growth that contribute to a higher rate of debt distress in low-income countries. All of these differences between the two groups are statistically significant at the 5 percent level, with the exception of the effect of growth, where the difference falls just short of significance at the 10 percent level.

As the ultimate interest is in predicting debt distress episodes based on a parsimonious set of variables, it is useful to also examine the out-of-sample predictive power of each of these first three specifications. To do this, each regression is reestimated using data through 1989. The estimated coefficients are then used together with the observed right-side variables to predict the outcome of each of the observations for the 1990s. In particular, a debt distress episode is predicted to occur if the predicted probability conditional on the observed data included in each regression is greater than the unconditional probability of distress in the pre-1990 sample. This unconditional probability is 0.38 in the full sample, 0.45 for the low-income country subsample, and 0.30 for the middle-income country subsamples. The predictive power of the forecasts is summarized by reporting the fractions of all observations after 1990 that are correctly predicted, as well as the success rate for distress episodes and normal time episodes separately.

The overall success rates are quite respectable, at 75 percent among lowincome countries and 78 percent among middle-income countries. To put these success rates in perspective, note that using only the historical unconditional rate of debt distress to predict future debt distress would yield a success rate of 50 percent among low-income countries and 58 percent among middle-income 
countries. ${ }^{13}$ The additional information in the three right-side variables therefore increases the success rate relative to this naive forecast by 20 to 25 percentage points. Note also that the success rate for predicting normal time episodes is even higher.

Overall, these results suggest that a quite parsimonious empirical model can do a reasonable job of accounting for patterns of debt distress over the past 25 years. Moreover, the out-of-sample forecasting power of the model is quite good. Before turning to the policy implications of this finding, this basic specification is first subjected to several robustness checks.

\section{Robustness of Core Specification: Does the Type of Debt Matter?}

To investigate the extent to which debt distress is affected by the type of external debt, external debt is distinguished along three dimensions. First is a variable measuring the share of external debt that is public and publicly guaranteed. Second is a variable measuring the share of external debt that is owed to official creditors, consisting of bilateral loans by governments as well as loans from multilateral organizations. Lastly, there is the concessionality of external debt, measured as one minus the ratio of the present value of debt to the nominal value of debt. Each of these variables is added in turn to the core specification for all countries and for low-income countries alone. ${ }^{14}$

All three characteristics of debt are significantly associated with the risk of debt distress (table 4). In particular, the greater the share of debt that is public or publicly guaranteed and the greater the share of debt owed to official creditors, the lower is the risk of debt distress. Also, the lower risk of debt distress, the greater the concessionality of debt. This last result may not be surprising because more concessional debt generally has lower immediate debt service obligations than less concessional debt. To the extent that debt distress is triggered by difficulties in meeting immediate debt service obligations, more concessional debt will be less likely to lead to debt distress. The finding that countries that owe more to official creditors are less likely to experience debt distress is more interesting. One interpretation is that official creditors are more likely to engage in "defensive lending," providing new loans to ensure that old loans are repaid. Another interpretation is that loans from official creditors tend to be more concessional and for reasons just given are therefore easier to service. One crude way to disentangle these two hypotheses is to put both the share owed to official creditors and the concessionality rate in the same regression. When

13. Suppose that the fraction of distress episodes observed in the past is $p$ and that distress is randomly predicted for a fraction $p$ of future events and no distress for the remaining fraction 1- $p$. Then the success rate of such a forecast based only on the unconditional historical rate of distress would be $p^{2}+(1-p)^{2}$. Because the historical rate of distress during the period before 1989 is $p=0.5$ for low-income countries and $p=0.3$ for middle-income countries, this yields the success rates given in the text.

14. Ideally, the partial effects of these three characteristics of debt would be estimated. Unfortunately, all three are quite strongly correlated at about 0.6 across observations. Given the small sample, multicollinearity problems prevent pinning down the partial effects precisely. 


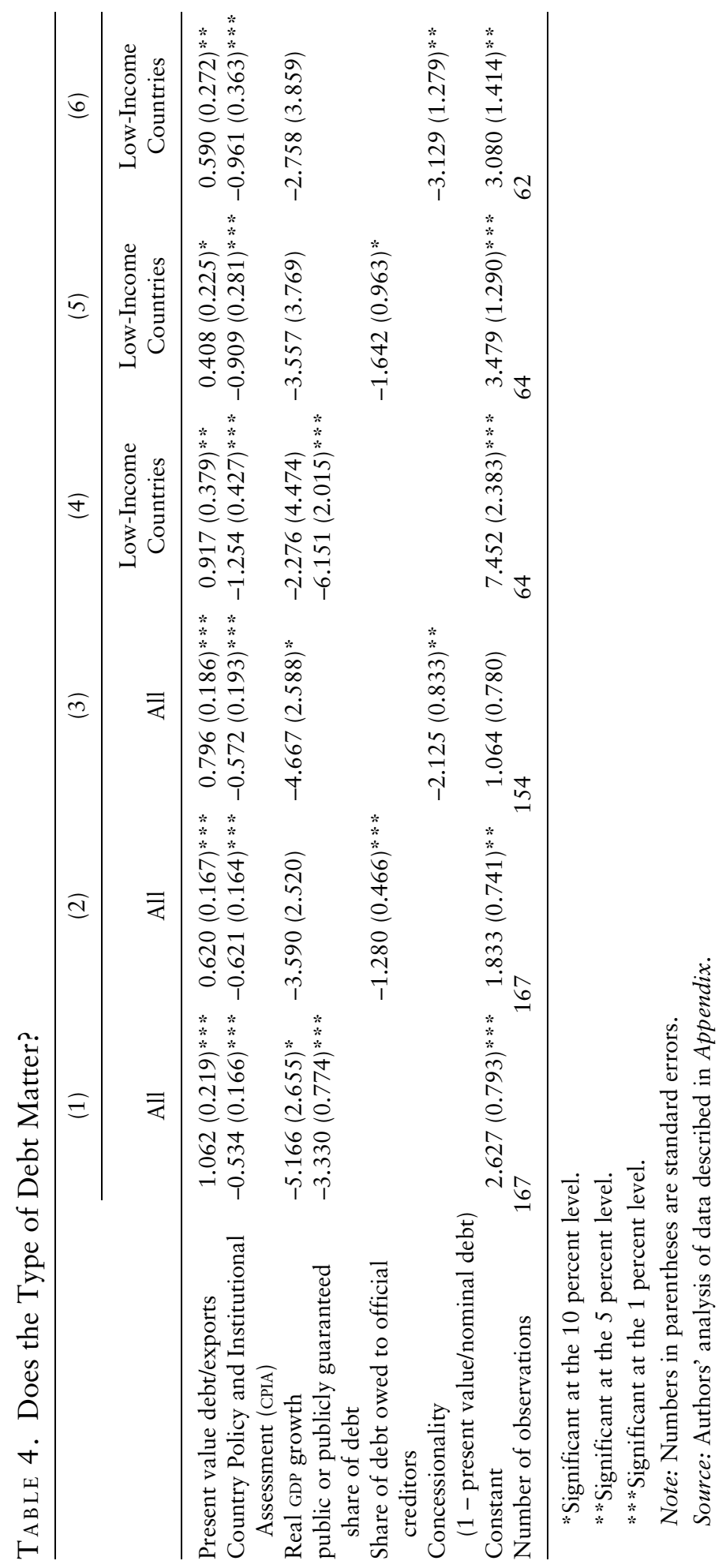


this is done, concessionality is found to be significant, whereas the official creditor share is not (results not reported). This is suggestive-but hardly conclusive-evidence against the "defensive lending" hypothesis.

\section{Policy Endogeneity and the Role of Shocks}

A potential concern with the results is that the CPIA measure of policy could be endogenous, in one of two ways. One possibility is that the CPIA is simply proxying for the indicators of debt distress. For example, it could be that World Bank country economists assign poor CPIA scores to countries that are running arrears or are negotiating a Paris Club agreement. The first defense against this possibility is the use of lags of the CPIA-CPIA in the year before the distress or normal time episode begins. Nevertheless, it could be that lagging the CPIA just one year is not sufficient, if for example, the CPIA scores are based on information that a Paris Club deal is likely to happen soon. When the CPIA is lagged by three years to eliminate the possibility of a mechanical correlation between distress and CPIA scores capturing actual or imminent distress, this further lagged measure of policy remains a highly significant predictor of debt distress (columns 1 and 4 of table 5). ${ }^{15}$ As the lag lengthens, however, the CPIA score unsurprisingly becomes less significant (results not reported). However, the significance of the one-year and three-year lagged CPIA scores in predicting debt distress is unlikely to reflect primarily reverse causation from future distress outcomes to current CPIA scores because that would require remarkable foresight on the part of World Bank staff who produce CPIA scores.

The second potential endogeneity problem is that the CPIA is simply proxying for other omitted country characteristics that also matter for debt distress. These might be macroeconomic instability in the country or deep institutional characteristics such as protection of property rights. Another possibility comes from the findings of Reinhart, Rogoff, and Savastano (2003) that a country's history of default and bad policy is a robust predictor of investors' perceptions of the likelihood of sovereign default. Countries with weak property rights, high macroeconomic instability, or a history of default might be more likely both to experience debt distress and to receive worse CPIA scores. To the extent that such factors are time invariant, the usual strategy is to difference them away and focus on the within-country variation in debt distress, debt burdens, policies, and growth. As discussed in more detail below, this simple differencing strategy is not an option in the nonlinear probit specification used here. The next section uses a dynamic panel probit estimator that allows for unobserved countryspecific sources of heterogeneity that help address this problem.

For now, direct controls are introduced for some of these country characteristics. Property rights protection is measured using the "rule of law" indicator

15. The CPIA variable itself is quite persistent over time. By sheer coincidence the correlation between the first and second lag of the CPIA in the sample is one, so the results using the second lag are not reported. The correlation between the first and third lag of the CPIA in the sample is 0.90 . 


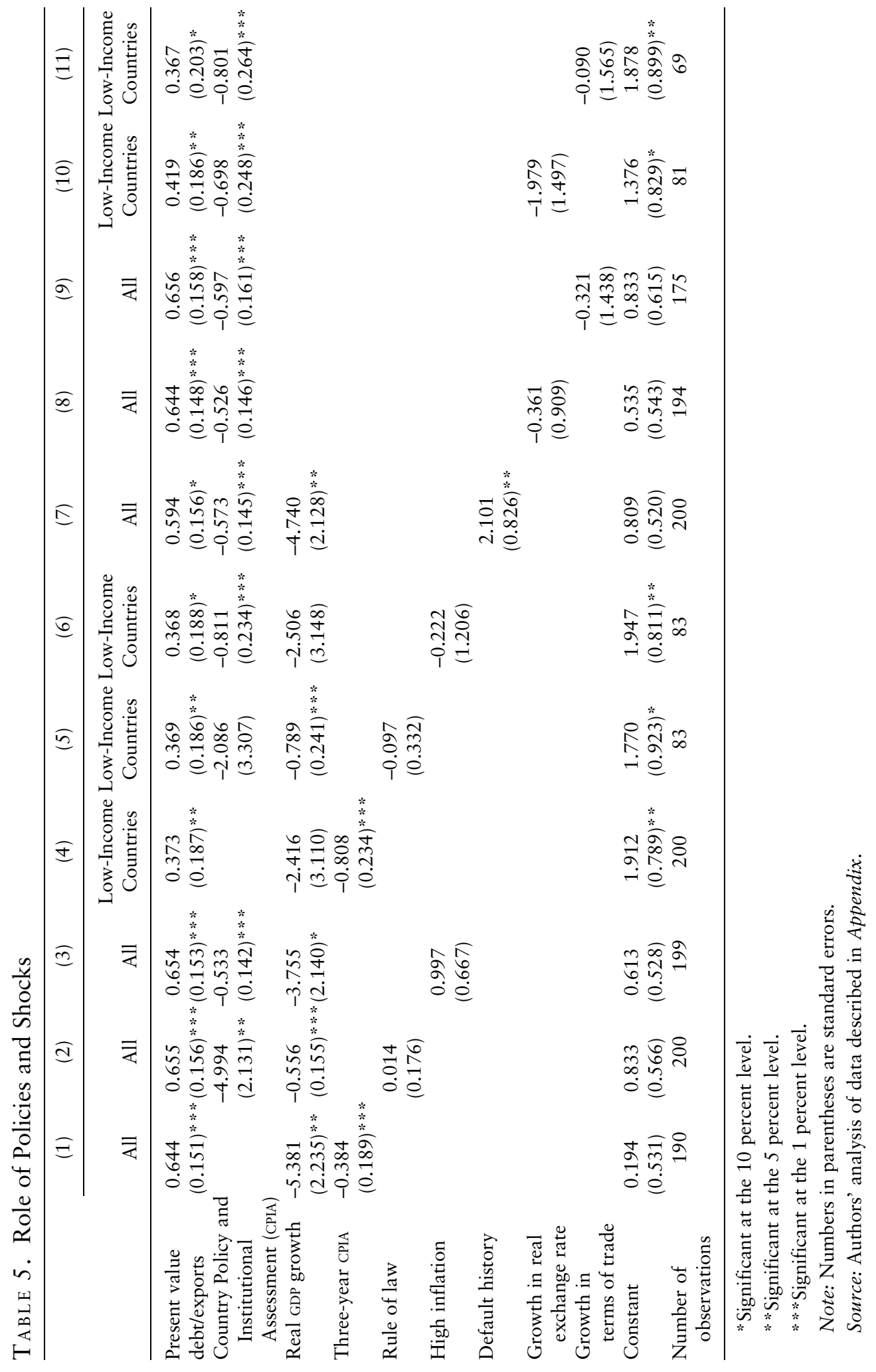


constructed by Kaufmann, Kraay, and Mastruzzi (2005). Macroeconomic instability is measured as the proportion of years in the sample period when inflation was greater than 40 percent a year. These control variables are added to the core specification for all countries and for low-income countries in columns $2,3,5$, and 6 of table 5 . Including these variables reduces the magnitude of the effect of policy somewhat compared with the results reported in table 3 , but the direct effect of the CPIA remains highly significant.

To directly investigate a country's history of default on its external obligations as a predictor of debt distress, the database of default episodes compiled by Reinhart, Rogoff, and Savastano (2003) is used to identify the fraction of years between independence (or 1824, whichever is later) and 1980 in which a country was in default on its external borrowing. Although this default history variable is significant for the full sample of observations, the CPIA remains highly significant as well (column 7 of table 5). ${ }^{16}$ From all of this, as well as the results described below, there can be reasonable confidence that endogeneity of the CPIA in the sense defined here is not driving the findings.

The analysis also attempts to isolate particular shocks that might trigger debt distress. The real GDP growth variable is replaced by measures of real exchange rate movements (columns 8 and 10 of table 5) and fluctuations in the terms of trade (columns 9 and 11). The rate of change in the real exchange rate relative to the U.S. dollar is constructed using changes in the nominal exchange rate and GDP deflators. Positive values of this variable correspond to real depreciations, which would be expected to raise the risk of debt distress by making dollar-denominated debt service obligations more expensive in domestic terms. The income effect of terms of trade change is measured as the current local currency share of exports in GDP times the growth rate of the local currency export deflator minus the share of imports in GDP times the growth rate of the import deflator. Adverse terms of trade shocks lower export earnings and income and might also trigger debt servicing difficulties. Despite the prior plausibility of these two shocks, virtually no evidence is found that they are significant predictors of debt distress. For terms of trade shocks this may not be too surprising, as Raddatz (2005) documents that these shocks account for only a small share of the variation in output in low-income countries. The results for real exchange rate movements also echo the negative findings of McFadden and others (1985) mentioned earlier. The results continue to show, however, that debt burden and policy are highly significant.

\section{Robustness of Core Specification: Dynamic Panel Probit Estimates}

The robustness checks conclude with a dynamic panel probit specification used to investigate the extent to which unobserved country characteristics, as well as

16. The impact of the default history variable cannot be estimated separately in the low-income sample because this variable is by coincidence equal to zero for all of the normal time episodes among lowincome countries, creating a singularity in the probit regression. 
countries' history of distress, matter for the current likelihood of distress. The following dynamic probit specification with unobserved country-specific effects is estimated:

$$
P\left[y_{c t}=1\right]=\boldsymbol{\Phi}\left(\boldsymbol{\beta}^{\prime} \mathbf{X}_{c t}+\rho \cdot y_{c, t-}+\mu_{c}\right)
$$

where $y_{c, t-}$ denotes the value of the distress indicator in the episode immediately prior to the one occurring at time $t$ in country $c ; \rho$ is a parameter capturing the persistence of distress, and $\mu_{c}$ is an unobserved country-specific time-invariant effect capturing unobserved country characteristics that influence the probability of debt distress.

This empirical model generalizes the one used so far in two important respects. First, it allows for serial dependence in the likelihood of debt distress by permitting the past value of the outcome variable (distress or not) to affect the probability that the current outcome will be distress. This captures in a very straightforward way the possibility that once a country has experienced debt distress it is more likely to do so in the future. Second, this model allows for unobserved country effects that influence the probability of distress in all periods for a given country. Importantly, there is no need to assume that the unobserved country effects are independent of the observed right-side variables. Thus there is no need to be concerned that the significance of the findings is being driven by omitted time-invariant country characteristics, such as property rights protection or a history of macroeconomic instability, that might affect the probability of debt distress and also be correlated with the included right-side variables.

The presence of unobserved country-specific effects complicates the estimation of the model. As noted, they cannot be eliminated by a differencing transformation common in linear panel data models. Moreover, a lagged dependent variable presents the familiar initial conditions problem: loosely, it cannot be ignored that by construction the lagged dependent variable is correlated with the unobserved country effect. This model is estimated by applying the initial conditions correction suggested by Wooldridge (2005). He proposes modeling the individual effect as a linear function of the initial observation on the dependent variable for each country, as well as time averages of all of the right-side variables. He also shows that this specification can be simply estimated using standard random-effect probit software, as long as the list of explanatory variables is augmented with the initial value of the dependent variable and time averages of all of the right-side variables for each country.

As before, debt indicators, policy, and growth remain significant predictors of the probability of debt distress in the full sample, and in the low-income country sample only debt and policies matter (table 6). The point estimates of the coefficients on debt and on policy are also quite close to those shown in table 3. No evidence is found that debt distress in the previous period significantly raises the probability of distress in the next period, after debt burdens, policy, and growth are controlled for. Taken together, these results suggest that unobserved 
Table 6. Dynamic Probit Results

\begin{tabular}{lcc}
\hline & All & Low-Income Countries \\
\hline Lagged dependent variable & $-0.641(0.451)$ & $-0.311(0.736)$ \\
Present value debt/exports & $0.628(0.256)^{* * *}$ & $0.557(0.334)^{*}$ \\
Country Policy and & $-0.522(0.260)^{* *}$ & $-1.486(0.520)^{* * *}$ \\
$\quad$ Institutional Assessment (CPIA) & $-8.237(3.407)^{* * *}$ & $-6.122(5.791)$ \\
Real GDP growth & $0.031(0.502)$ & $0.381(0.808)$ \\
Initial dependent variable & $0.152(0.363)$ & $-0.323(0.409)$ \\
Average present value & & \\
$\quad$ debt/exports & $-0.153(0.326)$ & $0.700(0.560)$ \\
Average CPIA & $5.839(4.729)$ & $2.701(7.612)$ \\
Average real GDP growth & $1.100(0.859)$ & $2.094(1.408)$ \\
Constant & 191 & 78 \\
Number of observations & 87 & 39 \\
Number of countries & & \\
\hline
\end{tabular}

*Significant at the 10 percent level.

* Significant at the 5 percent level.

$* *$ Significant at the 1 percent level.

Note: Numbers in parentheses are standard errors.

Source: Authors' analysis of data described in Appendix.

time-invariant country characteristics are not responsible for the main results and that the observed persistence of debt distress is due mostly to country effects and the persistence of debt burdens, policies, and shocks rather than to a recent history of distress itself. ${ }^{17}$

\section{Policy Implications}

The analysis has shown that the likelihood of debt distress in low-income countries depends not only on debt burdens but also on the quality of a country's policies and institutions. This finding has important implications for the lending strategies of official creditors such as the World Bank. The basic point is that assessments of the appropriateness of a country's debt burden should reflect the quality of the country's policies and institutions. The empirical results indicate a significant tradeoff between debt burdens and policy: countries with better policies and institutions can carry substantially higher debt burdens than countries with worse policies and institutions without increasing the risk of debt distress.

Figure 3 highlights this tradeoff. Consider a hypothetical country with a growth rate of 3.6 percent (the mean of the sample). For the indicated value of the CPIA on the $x$-axis, the level of the present value of debt relative to exports is

17. This last result contrasts with the finding of McFadden and others (1985), who do find evidence for state dependence in episodes of debt-servicing difficulties. 
Figure 3. Policies and Debt Distress

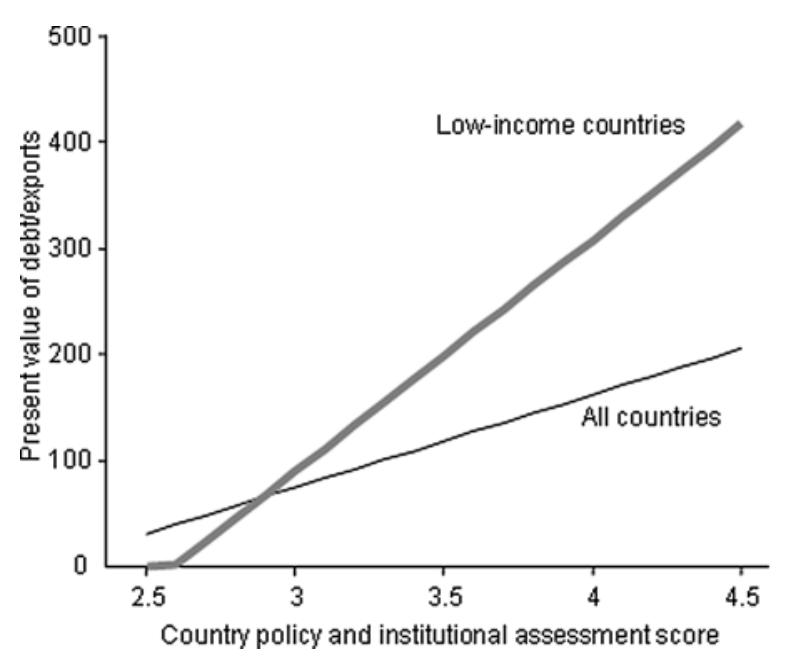

Source: Authors' analysis of data described in Appendix.

computed that would be consistent with a predicted probability of debt distress equal to 39 percent, which corresponds to the unconditional mean in the sample of low-income countries (truncating negative values at zero). ${ }^{18}$ The same relationship between policy and debt is reported based on the estimates pooling data for all countries.

The tradeoffs between debt and policy are considerable. For the estimates based on low-income countries, a country with average growth and poor policy (corresponding to a CPIA score of 3 , roughly in the first quartile of the sample) would be able to tolerate a present value of debt to exports of about 100 percent. In contrast, a country with good policy (corresponding to a CPIA score of 4 , in the fourth quartile of the sample) would be able to tolerate a debt level nearly three times higher with the same distress probability. For the estimates based on all countries, the tradeoffs are flatter. The implied debt level for a poor policy country with a CPIA of 3 would be 75 percent, whereas for a fairly good policy country with a CPIA of 4 it would be 160 percent.

Of course, for lower debt distress probabilities these lines would shift down, corresponding to lower levels of debt for any level of policy, and for higher debtdistress probabilities the line would shift up, corresponding to higher levels of debt for any level of policy. In addition, the precise magnitudes of the effects of differences in debt and policy on these implied debt levels depend on all of the estimated coefficients in the regressions on which these estimates are based, and

18. These implied debt levels are obtained by solving $p=\Phi\left(\beta_{0}+\beta_{1} \times\right.$ Debt $+\beta_{2} \times$ Policy $+\beta_{3} \times$ Growth) for debt, where $p$ is the desired probability of debt distress. 
these are subject to margins of error and vary across specifications. Thus, these numbers provide only a rough order of magnitude of the effects of policies on the level of debt consistent with a given distress probability.

The second policy implication is that the risk of debt distress should be taken into account when deciding the terms of resource transfers to low-income countries. The point here is simple. In recent years large increases in flows of development finance have been advocated to help countries meet the Millennium Development Goals. If these flows are provided in the form of concessional loans, as they have been in the past, many low-income countries are likely to see very sharp increases in their debt burdens. This could easily undo the reductions in debt burdens due to past debt relief efforts, which could thus have little lasting impact on the risk of debt distress.

Consider this simple hypothetical calculation for the 28 countries that have received debt relief under the HIPC Initiative. Between 1990 and 2003 these countries as a group received $\$ 58$ billion in disbursements of mostly concessional loans from official creditors. Given the calls for much greater aid to these countries, it is not inconceivable that these countries would receive the same amount of disbursements over the next five years. Now assume that the rate of concessionality of this new lending is the same as it is on the stock of debt outstanding as of 2003 and suppose further that it is distributed across countries in the same proportions as past official lending. This permits calculating a hypothetical present value of debt five years into the future, which can be thought of as corresponding to a rapid scaling-up in aid in the form of development lending to these countries with no change in the terms of these loans. Under this scenario the ratio of the present value of debt to exports would rise from a median of 157 percent to a median of 299 percent for these 28 countries. Based on the estimates in column 2 of table 3 and assuming no change in policies or growth performance, the estimated risk of debt distress would rise from a median of 33 percent (based on end-2003 data) to 52 percent. If exports in these countries are assumed to grow at their historical rate over the next five years, the increase in the ratio of the present value of debt to exports would be smaller, but still substantial, rising to 248 percent of exports for the median country.

This simple example illustrates how a large scaling-up in loan-based aid to low-income countries, without significant changes in the terms of these loans, is likely to result in sharp increases in external debt burdens and in the risk of debt distress. To avoid this, grants must make up a greater share of development assistance. For countries with a given quality of policies the share of grants will need to be significantly higher where debt distress probabilities are high and lower where distress probabilities are low. This implication is also consistent with the results in columns 3 and 6 of table 4, which show that the greater the concessionality of debt, the lower is the risk of debt distress.

Grants should not, however, supplant loans one for one in nominal terms in countries where the risk of debt distress is high, for two reasons. First, replacing 
loans with grants equal to the face value would represent a vastly larger resource transfer than is currently envisioned by donors, and obtaining the necessary financing would be difficult. Second, such a scheme would implicitly "reward" countries implementing weak policies with greater overall resource transfers, undermining efforts to target aid to countries with good policies.

One scheme for calibrating the share of grants without exacerbating these targeting problems would be a three-step process that begins by converting the total amount of new lending into its grant equivalent from the donors' perspective (subtracting the present value of future debt-service obligations from the face value of the new lending). Next, this grant equivalent could be allocated across countries following an aid allocation rule that recognizes the importance of "needs" (the prevalence of poverty) and aid effectiveness (a function of the quality of policies and institutions of the recipient country, as is currently done by the International Development Association, the soft-loan window of the World Bank). Finally, for countries below a specified distress probability (where the capacity for servicing debt in the future is considered relatively good), this grant equivalent could be grossed-up into a much larger amount of concessional lending with the same grant equivalent.

Such a scheme has many advantages. It avoids the large and likely unsustainable increases in debt burdens that would follow from large-scale across-the-board new lending to low-income countries. This scheme not only ensures that resources are targeted to countries with high poverty and good policies but also provides an additional reward for good policy. Countries would prefer to be able to gross-up as much of their grant-equivalent allocation as possible into lending, and improvements in policy can create additional headroom for new borrowing by lowering the probability of debt distress. Finally, this scheme would not require any new commitments by donors to finance new grants, beyond the new transfers in grant equivalent terms implicit in donor commitments to lending at existing rates of concessionality. This is because donors would be committing to the same transfer to a country whether they provide only the grant element or they convert the grant element into a loan with the same grant equivalent. If anything, the resource transfer from the perspective of the donor might be even smaller, to the extent that calibrating the fraction of loans to the probability of debt distress results in higher actual repayment rates in the future. ${ }^{19}$

In summary, this article has shown that the risk of debt distress depends significantly on a small set of factors: debt burdens, policies and institutions,

19. In 2005 the IMF and World Bank adopted a joint Debt Sustainability Framework for low-income countries that endorsed a greater role for grants to reduce the risk of debt distress. It spelled out a set of policy-dependent debt sustainability thresholds that are based on the empirical analysis in the working paper version of this article (Kraay and Nehru 2004). IDA has chosen to implement a modified version of the proposal advanced here and in the working paper version of this article. The key difference, however, is that the IDA proposal converts the full amount of proposed lending to countries at risk of debt distress into grants, less a small discount. This results in greater resource transfers to countries at risk of debt distress and so reduces the policy selectivity of IDA resource transfers. 
and shocks. This finding is robust to several checks, and the empirical model does a reasonable job of predicting future debt distress. Although at some level these results should not be too surprising, they do have important implications for how to finance resource transfers to low-income countries. The results indicate that the probability of debt distress is already high in many low-income countries and is likely to increase sharply if the large-scale development finance required to meet the Millennium Development Goals is provided in the form of concessional lending at historical levels of concessionality. The article also proposed a simple scheme of financing resource transfers to low-income countries in a way that controls the probability of debt distress, provides good incentives to borrowers, and does not involve additional donor commitments to finance large-scale new grants.

\section{Appendix}

\section{Data Sources}

The debt-distress indicator requires data on arrears, Paris Club deals, and IMF programs. Data on arrears are taken from the World Bank's Global Development Finance. The arrears data consist of arrears to official and private creditors and are expressed as a share of total debt outstanding. Paris Club deals come from the Paris Club Web site (http://www.clubdeparis.org). For IMF programs data on commitments under Standby Arrangement and Extended Fund Facility programs and data on the size of each country's quota, used to normalize commitments, are from the IMF's International Financial Statistics.

The core regressions include the present value of debt as a share of exports. Data on the numerator of this measure come from Dikhanov (2003). He applies currency-, maturity-, and time-specific market interest rates to the flow of debtservice obligations on a loan-by-loan basis, using data from the World Bank's Debtor Reporting System database to arrive at a historical series of the present value of public and publicly guaranteed debt for all developing countries since 1970. The denominator is exports in current U.S. dollars taken from the World Bank's World Development Indicators Database. The same data source is used to construct the growth rate of GDP in constant local currency units for the growth variable. The CPIA variable is a confidential policy assessment produced by World Bank country economists. Details on its structure and disclosure of recent data are available at http://www.worldbank.org. Data on the share of debt owed to official creditors and on the share of public and publicly guaranteed debt in total debt (at face value) are from Global Development Finance.

The robustness checks use the rule of law measure constructed by Kaufmann, Kraay, and Mastruzzi (2005) and countries' default history as reported by Reinhart, Rogoff, and Savastano (2003). A dummy variable for years of high inflation is constructed using consumer price index (CPI) inflation data obtained from the World Development Indicators Database, supplemented by data on the 
growth rate of the GDP inflator when CPI inflation is not available. The real exchange rate index is the bilateral real exchange rate relative to the U.S. dollar, using the price index of GDP in the home country and the United States. Data on these variables also come from the World Development Indicators Database http://www.worldbank.org.

\section{REFERENCES}

Aylward, Lynn, and Rupert Thorne. 1998. “An Econometric Analysis of Countries' Repayment Performance to the International Monetary Fund.” IMF Working Paper 98/32. International Monetary Fund, Washington, D.C.

Berg, Andrew, and Jeffrey Sachs. 1988. "The Debt Crisis: Structural Explanations of Country Performance." Journal of Development Economics 29(3):271-306.

Birdsall, Nancy, C. Claessens, and I. Diwan. 2003. "Policy Selectivity Forgone: Debt and Donor Behavior in Africa." World Bank Economic Review 17(3):409-35.

Cline, William. 1984. International Debt: Systemic Risk and Policy Response. Washington, D.C.: Institute of International Economics.

Cohen, Daniel. 1996. “The Sustainability of African Debt.” Policy Research Working Paper 1691. World Bank, Washington, D.C.

Collins, Susan. 2003. "Probabilities, Probits, and the Timing of Currency Crises." Georgetown University, Department of Economics, Washington, D.C.

Detragiache, Enrica, and Antonio Spilimbergo. 2001. "Crises and Liquidity: Evidence and Interpretation.” IMF Working Paper 01/2. International Monetary Fund, Washington, D.C.

Dikhanov, Yuri. 2003. "Reconstruction of Historical Present Value of Debt for Developing Countries, 1980-2001: Methodology and Calculations.” World Bank, Development Economics Data Group, Washington, D.C.

IMF (International Monetary Fund). Various years. International Financial Statistics. Washington, D.C.

—. 2002. "Evaluation of the Prolonged Use of Fund Resources." Independent Evaluation Office, International Monetary Fund, Washington D.C.

Kaufmann, Daniel, Aart Kraay, and Massimo Mastruzzi. 2005. "Governance Matters IV: Updated Governance Indicators for 1996-2004.” World Bank Policy Research Working Paper 3630. World Bank, Washington, D.C.

Kraay, Aart, and Vikram Nehru. 2004. "When is External Debt Sustainable?” Policy Research Working Paper 3200. World Bank, Washington, D.C.

Lloyd-Ellis, H., G. W. McKenzie, and S. H. Thomas. 1990. "Predicting the Quantity of LDC Debt Rescheduling." Economics Letters 32(1):67-73.

Manasse, Paolo, Nouriel Roubini, and Axel Schimmelpfenning. 2003. "Predicting Sovereign Debt Crises." IMF Working Paper 03/221. International Monetary Fund, Washington, D.C.

McFadden, Daniel, Richard Eckaus, Gershon Feder, Vassilis Hajivassiliou, and Stephen O'Connell. 1985. "Is There Life After Debt? An Econometric Analysis of the Creditworthiness of Developing Countries." In Gordon Smith and John Cuddington, eds., International Debt and the Developing Countries. Washington, D.C.: World Bank.

McKenzie, David. 2004. “An Econometric Analysis of IBRD Creditworthiness.” International Economic Journal 18(4):427-48.

Raddatz, Claudio. 2005. "Are External Shocks Responsible for the Instability of Output in Low-Income Countries?” Policy Research Working Paper 3680. World Bank, Washington, D.C.

Reinhart, Carmen, Kenneth Rogoff, and Miguel Savastano. 2003. “Debt Intolerance.” Brookings Papers on Economic Activity 1:1-74.

Underwood, John. 1991. "The Sustainability of International Debt.” World Bank, International Finance Division, Washington, D.C. 
Wooldridge, Jeffrey. 2005. "Simple Solutions to the Initial Conditions Problem in Dynamic, Nonlinear Panel Data Models with Unobserved Heterogeneity." Journal of Applied Econometrics 20(1):39-54.

World Bank. 2003. "Special Purpose Financial Statements and Internal Control Reports of the International Development Association.” In The World Bank Annual Report 2003. Vol. 2: Financial Statements and Appendixes. Washington, D.C.

- Various years. Global Development Finance. Washington, D.C.

—. Various years. World Development Indicators Database. Washington, D.C. 